\title{
Subjective memory complaints after electroconvulsive therapy: systematic review
}

\author{
Simon Vann Jones, ${ }^{1}$ Rick McCollum ${ }^{2}$
}

BJPsych Bulletin (2019) 43, 73-80, doi:10.1192/bjb.2018.45

${ }^{1}$ ST5, Cornwall Partnership Foundation Trust, Bodmin, UK; ${ }^{2}$ Consultant, Devon Partnership NHS Trust, Exeter, UK

Correspondence to Dr Simon Vann Jones (s.vannjones@nhs.net)

First received 31 Dec 2017, final revision 23 Apr 2018, accepted 31 May 2018

(C) The Authors 2018. This is an Open Access article, distributed under the terms of the Creative Commons Attribution-NonCommercialNoDerivatives licence (http:// creativecommons.org/licenses/by-ncnd/4.0/), which permits noncommercial re-use, distribution, and reproduction in any medium, provided the original work is unaltered and is properly cited. The written permission of Cambridge University Press must be obtained for commercial re-use or in order to create a derivative work.
Aims and method Few studies have looked at subjective memory impairment from electroconvulsive therapy (ECT) after treatment completion. We aimed to systematically review all available evidence for subjective post-treatment effects.

Results We included 16 studies in this review. There was considerable betweenstudy heterogeneity in clinical population, ECT modality and assessment scales used. The most common assessment scale (eight studies) was the Squire Subjective Memory Questionnaire. The majority of studies reported an improvement in subjective memory after ECT, which correlated with improved depression scores. Subjective complaints were fewer in studies that used ultra-brief pulse ECT. Longer pulse widths were associated with more subjective complaints, as was female gender and younger age of treatment in the largest study.

Clinical implications There is considerable heterogeneity between studies, limiting meaningful conclusions. Ultra-brief pulse ECT appears to result in fewer subjective complaints.

\section{Declaration of interest None.}

Keywords Electroconvulsive therapy; memory; cognition; depression; side-effects; treatments.
Electroconvulsive therapy (ECT) is an effective treatment for major depression; however, there is debate around the specific long-term effects of the treatment on memory and the acceptability of this to patients. ${ }^{1}$ There is wide variation in the post-treatment satisfaction rates after ECT, with previous studies showing that the percentage of patients who would consider having a second course of ECT varies between $36 \%$ and $98 \%$. $^{2}$ Multiple studies have shown that dissatisfaction with ECT is related to feeling under-informed of potential side-effects. ${ }^{3-7}$

Pre-procedural fear and post-procedural assumptions that deleterious cognitive changes were a direct result of the treatment have been identified as the two areas most likely to lead to a negative view of ECT. ${ }^{8}$ Evidence suggests that clinicians tend to overestimate the effects of medical treatments and underestimate harm, so being able to accurately quantify the additional risk that ECT poses to subjective memory independent of the effects of depression would help both clinicians and patients alike and may improve outcomes. ${ }^{9,10}$ This review aims to summarise all studies that have assessed the post-treatment effects of ECT on meaningful memory loss.

\section{Methods}

This systematic review was completed in accordance with Preferred Reporting Items for Systematic Reviews and Meta-Analyses reporting guidelines (Fig. 1).

\section{Inclusion criteria}

Studies measuring subjective memory at baseline followed by at least one measurement after the completion of treatment, using a clearly described scale (such as the Squire Subjective Memory Questionnaire, SSMQ ${ }^{11}$ ), or questions that specifically assessed subjective memory were included.

A follow-up period of at least $24 \mathrm{~h}$ after the completion of therapy was considered sufficient to allow enough time for the acute effects of the final seizure to have passed and no limit was placed on the maximum length of follow-up. Both prospective and retrospective studies were included. Only published studies were included and studies in all languages were considered.

Studies measuring memory only during treatment were excluded. Squire's original studies from 1979 were excluded.

\section{Information sources}

The online databases PubMed, Google Scholar, Embase, PsychINFO and Cumulative Index of Nursing and Allied Health Literature (CINAHL) were searched for eligible studies. The following search terms and Boolean operators were used in PubMed as examples: 'subjective AND (ECT OR electroconvulsive)', 'memory AND (ECT OR electroconvulsive'). 


\section{Study selection}

Abstracts were screened for inclusion by two independent reviewers. Where any disagreement arose between reviewers, the full paper was requested. All full papers were read and scrutinised by both reviewers independently before deciding to whether to include them in the final review. Screened papers references were searched to identify any further papers.

\section{Data collection process}

Both reviewers used the same data extraction form and completed the data collection independently. Both reviewers screened all papers deemed eligible for inclusion and at the end of this process, data extraction forms were compared for agreement. Where data were missing from both forms and felt to be of significant value to the study question, the authors of the study were contacted directly.

\section{Data items}

The variables of interest from each study included the number and diagnoses of the patients involved in the study, the modality of ECT (e.g. unilateral versus bilateral or brief pulse versus ultra-brief pulse), the memory assessment method used, the results of this and the authors main conclusions.

\section{Risk of bias within and across studies}

Several sources of bias were considered including attrition bias, given the patient population in question, and also the risk of acquiescence and reporting or detection bias if memory assessments were carried out by the same team that performed the treatment. There was also a two-way risk of recall bias in this patient group with patients vulnerable to both underestimating and overestimating the extent of their memory impairment before ECT, because of the extent of their depression and the effect this is known to have on memory.

All studies described methods for dealing with missing data if applicable, with most studies reporting complete-case analysis or intention to treat.

\section{Results}

A total of 877 abstracts were identified for potential inclusion, of which 52 were felt to warrant full-paper requests. From these 52 and their reference lists, 16 papers were selected for inclusion in the final review (Fig. 1). The main reasons for rejecting papers were no baseline measure of subjective memory, paper measured objective memory only, no measurement of subjective memory beyond the final treatment and insufficient time between the final treatment and measurement of memory.

\section{Synthesis of results}

Because of significant clinical and methodological heterogeneity, it was not possible to perform a meta-analysis on the included studies. No two studies measured a comparable patient population, on the same scale, using the same ECT modality, at the same time points (Table 1).

\section{Participants}

We found that 15 out of 16 studies reported that major depressive disorder in unipolar or bipolar depression was the indication for treatment in the majority of patients. One study reported $59.3 \%$ of their sample being treated for mania. ${ }^{12}$ Two studies reported use in patients with schizophrenia and schizoaffective disorders, although it was unclear whether these patients were treated for their depressive or primary psychotic symptoms. ${ }^{13,14}$

\section{Assessment tool used and time points}

The most commonly used tool for measuring subjective memory change was the SSMQ, with eight studies using all or part of this scale. ${ }^{6,12,15-20}$ This is an 18-item questionnaire assesses various aspects of subjective memory on a Likert scale from -4 (much worse) to +4 (much improved), providing a total score comparing current memory with a previous time point. For the purposes of these studies, it was assumed that memory was being compared to premorbid memory, although this was not explicitly stated in any study. Five of the six studies that provided group-averaged SSMQ scores showed sustained improvements from baseline after ECT treatment (Fig. 2).

\section{Modality}

Pulse width

Four studies included patients who had received ultra-brief pulse width. ${ }^{2,15,17,21}$ Two of these compared brief with ultrabrief and both found longer pulse widths were associated with more subjective complaints. ${ }^{15,21}$ One of these studies demonstrated that this difference was not accounted for by use of bilateral versus unilateral. ${ }^{21}$

\section{Laterality}

Eight studies favoured or exclusively used right unilateral electrode placements, three studies favoured bilateral, one used bifrontal, three used a combination of bilateral, bifrontal and unilateral, and one study compared bifrontal with unilateral.

\section{Discussion}

Studies showed wide variation in the length of follow-up period used to assess post-treatment memory. Although this does not allow a truly longitudinal picture, it does allow the possibility of assessing whether patterns may exist at different times points post-treatment.

\section{Short-term follow-up}

A retrospective analysis of 1212 medical records from the Swedish ECT treatment registry found, compared with a pre-treatment baseline, $26 \%$ reported worse subjective memory post-treatment, defined by a two-point deficit on 


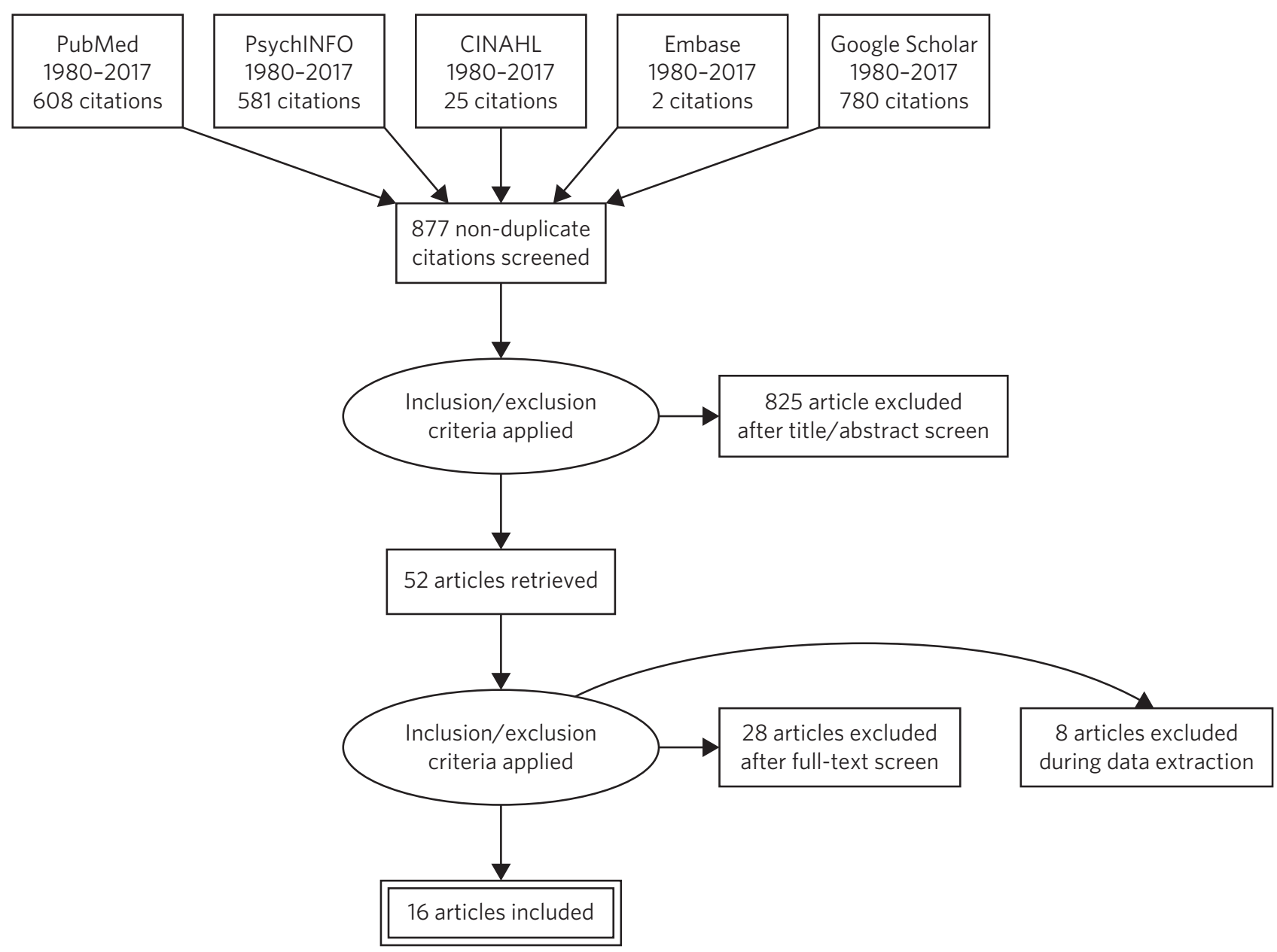

Fig. 1 Preferred reporting items for systematic reviews and meta-analyses flow diagram mapping search history. CINAHL, Cumulative Index of Nursing and Allied Health Literature database.

the subjective memory component of the Comprehensive Psychopathological Rating Scale questionnaire. ${ }^{21}$ In an attempt to stratify risk, the study found that more women suffered with subjective memory loss than men (31 v. 18\%) and more younger adults than adults aged over 65 years (32 v. 22\%). The large sample size adds validity to this finding. Patients were assessed within 1 week of treatment ending compared with the start of therapy, limiting the extrapolation of this data to long-term outcomes, and the majority of patients (91.6\%) received unilateral treatment. Short pulse wave and remission of depressive symptoms were associated with reduced subjective memory complaints and no dose effect was found.

A more recent study of 140 in-patients, $75 \%$ with bipolar depression, undergoing ECT found a significant negative correlation between number of treatments and deterioration in subjective memory score across diagnostic groups tested within days of treatment by the SSMQ. ${ }^{12}$

Contrary to these findings, the only study to use the Subjective Assessment of Memory Impairment found no change in scores amongst participants between pre-treatment and immediately after completing the course of ECT. ${ }^{14}$ Two smaller studies, using different measures, found similar findings. ${ }^{18,22}$
In a pragmatic study, an automated telephone system was used to intensively monitor day-to-day fluctuations in mood and memory in a small sample $(n=26)$ of patients undergoing out-patient ECT. ${ }^{17}$ Patients were asked daily questions related to subjective memory. Objective memory scores improved with time and were correlated with mood, whereas subjective memory scores remained stable. The authors suggested that objective scores could be used to counter subjective beliefs that may cause premature termination of ECT because of concerns over side-effects.

\section{Medium-term follow-up: up to 3 months}

Using the SSMQ, a 2013 study found that patients $(n=35)$ experienced a clinically meaningful and statistically significant improvement in subjective memory across most domains with no significant deterioration in any one domain, correlating with an improvement in depressive symptoms. ${ }^{15}$ This improvement was sustained after 3 months. A study of 48 patients in Belgium reported similar findings with improvements in SSMQ scores in both groups at 6 weeks post-treatment. ${ }^{2}$

In a case-control design involving 70 patients and 18 controls without depression, those in the ECT group reported worse subjective memory at baseline and a significant 


\begin{tabular}{|c|c|c|c|c|c|}
\hline Study (first author, year) & Participants & Questionnaire used & Modality & Assessment & Results summary \\
\hline Mohn $2016^{23}$ & $\begin{array}{l}n=31, \text { unipolar } \\
\text { depression }\end{array}$ & $\begin{array}{l}\text { Everyday Memory } \\
\text { Questionnaire }\end{array}$ & $\begin{array}{l}\text { Bifrontal, } n=1 ; \\
\text { unilateral, } n=22 ; \\
\text { mixed unilateral and } \\
\text { bilateral, } n=8\end{array}$ & $\begin{array}{l}\text { Baseline, } 6 \\
\text { weeks and } 6 \\
\text { months }\end{array}$ & $\begin{array}{l}\text { Pre-ECT, } 104.0 \\
\text { (SD 37.9); } 6 \text { weeks } \\
\text { post-treatment, } 107.9 \\
\text { (SD 43.6); } 6 \text { months } \\
\text { post-treatment, } 98.6 \\
\text { (SD 42.6); higher } \\
\text { score indicates worse } \\
\text { memory }\end{array}$ \\
\hline Brus $2017^{21}$ & $\begin{array}{l}n=1212,80 \% \\
\text { unipolar depression; } \\
20 \% \text { bipolar } \\
\text { depression }\end{array}$ & $\begin{array}{l}\text { Seven-point variant of } \\
\text { the 'failing memory' } \\
\text { component of the } \\
\text { Comprehensive } \\
\text { Psychopathological } \\
\text { Rating Score }\end{array}$ & $\begin{array}{l}86.9 \% \text { had more } \\
\text { than six treatments; } \\
91.6 \% \text { had unilateral } \\
\text { electrode placement }\end{array}$ & $\begin{array}{l}\text { Baseline and } \\
<1 \text { week } \\
\text { post-treatment }\end{array}$ & $\begin{array}{l}\text { Subjective memory } \\
\text { worsened in } 28 \% \text { of } \\
\text { the sample ( } 31 \% \\
\text { women v. } 18 \% \text { men; } \\
32 \% \text { young adults v. } \\
22 \% \text { adults aged over } \\
65 \text { years); longer } \\
\text { pulse widths } \\
\text { correlated with more } \\
\text { subjective complaints; } \\
\text { no difference between } \\
\text { bilateral and unilateral } \\
\text { placement }\end{array}$ \\
\hline Bag $2016^{12}$ & $\begin{array}{l}n=140,24.3 \% \\
\text { unipolar depression; } \\
59.3 \% \text { bipolar mania; } \\
\text { 16.4\% bipolar } \\
\text { depression }\end{array}$ & SSMQ & $\begin{array}{l}\text { Bilateral, brief pulse; } \\
\text { mean number of } \\
\text { sessions was seven } \\
\text { across all groups }\end{array}$ & $\begin{array}{l}\text { Baseline and } \\
\text { immediately } \\
\text { post-treatment }\end{array}$ & $\begin{array}{l}\text { Mean SSMQ score } \\
\text { dropped }-49.5 \text { points } \\
\text { between baseline and } \\
\text { end of therapy; } \\
\text { patients with bipolar } \\
\text { disorder reported less } \\
\text { complaints than } \\
\text { patients with unipolar } \\
\text { depression }\end{array}$ \\
\hline Kumar $2016^{14}$ & $\begin{array}{l}n=75,77 \% \text { unipolar } \\
\text { depression; } 10.7 \% \\
\text { bipolar type } 1 \\
\text { disorder; } 2.7 \% \\
\text { bipolar type } 2 \\
\text { disorder; } \\
\text { schizophrenia } 2.7 \% \text {; } \\
\text { schizoaffective } \\
\text { disorders } 5.3 \%\end{array}$ & $\begin{array}{l}\text { Subjective Assessment } \\
\text { of Memory Impairment }\end{array}$ & $\begin{array}{l}96 \% \text { received right } \\
\text { unilateral; the } \\
\text { majority received } \\
\text { brief pulse }\end{array}$ & $\begin{array}{l}\text { Baseline and } \\
1 \text { day } \\
\text { post-treatment }\end{array}$ & $\begin{array}{l}\text { No change in } \\
\text { subjective memory } \\
\text { score during therapy } \\
\text { despite objective } \\
\text { evidence of } \\
\text { impairment }\end{array}$ \\
\hline Mayur $2013^{15}$ & $\begin{array}{l}n=40, \text { unipolar } \\
\text { depression }\end{array}$ & SSMQ & $\begin{array}{l}\text { Right unilateral; } 50 \% \\
\text { ultra-brief pulse; } \\
50 \% \text { brief pulse }\end{array}$ & $\begin{array}{l}\text { Baseline, after } 8 \\
\text { sessions and } 3 \\
\text { months } \\
\text { post-treatment }\end{array}$ & $\begin{array}{l}\text { Brief pulse: }-21.6 \text { at } \\
\text { baseline }(n=19) \text {, } \\
-16.2 \text { at } 3 \text { months } \\
(n=10) \text {, } \\
\text { within-patient change } \\
\text { of }+12.7 \text {; ultra-brief } \\
\text { pulse: }-23.2 \text { at } \\
\text { baseline }(n-16),-0.8 \\
\text { at } 3 \text { months }(n=14) \text {; } \\
\text { within-patient change } \\
\text { of } 14.86\end{array}$ \\
\hline Fernie $2014^{16}$ & $\begin{array}{l}n=126, \text { unipolar } \\
\text { depression }\end{array}$ & SSMQ and PRMQ & Not described & $\begin{array}{l}\text { Baseline, } \\
1 \text { month, } 3 \\
\text { months and } \\
6 \text { months } \\
\text { post-treatment }\end{array}$ & $\begin{array}{l}\text { SSMQ improved from } \\
-14.1 \text { at baseline to } \\
-4.58 \text { at } 6 \text { months, } \\
\text { with the greatest } \\
\text { improvement seen } \\
1 \text { month after therapy: } \\
-1.59 \text { (SD } 2.73 \text { ); } \\
\text { PRMQ score improved } \\
\text { by approximately } 10 \% \\
\text { from baseline }\end{array}$ \\
\hline Fazzino $2013^{17}$ & $\begin{array}{l}n=26, \text { unipolar } \\
\text { depression }\end{array}$ & $\begin{array}{l}\text { Selected SSMQ } \\
\text { questions }\end{array}$ & $\begin{array}{l}17 / 26 \text { received right } \\
\text { unilateral; } 17 / 26 \\
\text { received ultra-brief } \\
\text { pulse width }\end{array}$ & $\begin{array}{l}3-7 \text { questions } \\
\text { daily for } 60 \text { days } \\
\text { (including } \\
\text { treatment) }\end{array}$ & $\begin{array}{l}\text { No change in } \\
\text { subjective memory } \\
\text { scores despite } \\
\text { objective memory } \\
\text { improvement }\end{array}$ \\
\hline
\end{tabular}




\begin{tabular}{|c|c|c|c|c|c|}
\hline Study (first author, year) & Participants & Questionnaire used & Modality & Assessment & Results summary \\
\hline $\mathrm{Ng} 2000^{22}$ & $\begin{array}{l}n=34, \text { unipolar } \\
\text { depression }\end{array}$ & $\begin{array}{l}\text { Self-Rating Scale of } \\
\text { Memory Function }\end{array}$ & Right unilateral & $\begin{array}{l}\text { Baseline, after } \\
\text { six treatments } \\
\text { and } 1 \text { month } \\
\text { post-treatment }\end{array}$ & $\begin{array}{l}\text { Improved subjective } \\
\text { memory score at end } \\
\text { of treatment; negative } \\
\text { correlated with HRSD } \\
\text { score }\end{array}$ \\
\hline $\begin{array}{l}\text { Schulze-Rauschenbach } \\
2005^{18}\end{array}$ & $\begin{array}{l}n=14, \text { unipolar } \\
\text { depression }\end{array}$ & SSMQ & $\begin{array}{l}\text { Right unilateral and } \\
\text { brief pulse width }\end{array}$ & $\begin{array}{l}\text { Baseline and } \\
\text { within } 1 \text { week } \\
\text { of completing }\end{array}$ & $\begin{array}{l}\text { 5.5-point } \\
\text { improvement in } \\
\text { SSMQ score, although } \\
\text { not statistically or } \\
\text { clinically significant }\end{array}$ \\
\hline Frith $1983^{24}$ & $\begin{array}{l}n=70, \text { unipolar } \\
\text { depression }\end{array}$ & $\begin{array}{l}\text { Single binary question: } \\
\text { 'do you experience } \\
\text { memory problems?' }\end{array}$ & $\begin{array}{l}\text { Bifrontal ECT, } \\
\text { median course of } \\
\text { eight sessions }\end{array}$ & $\begin{array}{l}\text { Baseline, after } \\
\text { treatment and at } \\
6 \text { months }\end{array}$ & $\begin{array}{l}\text { Sham ECT responders, } \\
\text { ECT responders and } \\
\text { sham ECT } \\
\text { non-responders all } \\
\text { reported improvement } \\
\text { in memory; ECT } \\
\text { non-responders } \\
\text { memory remained } \\
\text { stably poor }\end{array}$ \\
\hline Smith $2010^{19}$ & $\begin{array}{l}n=85, \text { unipolar } \\
\text { depression }\end{array}$ & SSMQ & $\begin{array}{l}\text { Bilateral ECT; half } \\
\text { had ten sessions of } \\
\text { continuation ECT } \\
\text { Half had } \\
\text { continuation } \\
\text { pharmacotherapy }\end{array}$ & $\begin{array}{l}\text { Baseline (post- } \\
\text { ECT), } 12 \text { weeks } \\
\text { and } 24 \text { weeks }\end{array}$ & $\begin{array}{l}\text { Both groups' SSMQ } \\
\text { scores significantly } \\
\text { improved from } \\
\text { baseline; study looked } \\
\text { at continuation } \\
\text { treatment only }\end{array}$ \\
\hline Sienaert $2010^{2}$ & $\begin{array}{l}n=48, \text { unipolar and } \\
\text { bipolar depression; } \\
23 \% \text { had psychotic } \\
\text { symptoms }\end{array}$ & SSMQ & $\begin{array}{l}\text { Ultra-brief bifrontal } \\
n=24 \text { and unilateral } \\
n=24\end{array}$ & $\begin{array}{l}\text { Baseline and } \\
6 \text { weeks }\end{array}$ & $\begin{array}{l}\text { 73\% patients were glad } \\
\text { they had ECT; SSMQ } \\
\text { performance strongly } \\
\text { correlated with } \\
\text { satisfaction on multiple } \\
\text { regression analysis but } \\
\text { also correlated with } \\
\text { depression score, so } \\
\text { may not be } \\
\text { independent }\end{array}$ \\
\hline Berman $2008^{26}$ & $\begin{array}{l}n=333, \text { unipolar } \\
\text { depression }\end{array}$ & CFQ memory subscale & $\begin{array}{l}40 \% \text { bilateral, } 34.7 \% \\
\text { unilateral, } 24.3 \% \\
\text { combination; } 14 \% \\
\text { sine-wave, } 86 \% \text { brief } \\
\text { pulse }\end{array}$ & $\begin{array}{l}\text { Baseline, } 1 \text { week } \\
\text { and } 24 \text { weeks }\end{array}$ & $\begin{array}{l}\text { Baseline } 14.97 \\
\text { (SD 6.75), } 1 \text { week } 13.01 \\
\text { (SD 6.39), } 24 \text { weeks } \\
\text { 14.05 (SD 6.85) } \\
\text { (higher scores indicate } \\
\text { greater impairment) }\end{array}$ \\
\hline Arts $2006^{25}$ & $\begin{array}{l}n=12, \text { bipolar and } \\
\text { unipolar depression }\end{array}$ & CFQ & Bilateral & $\begin{array}{l}\text { Baseline, } 5 \text { days } \\
\text { and } 30 \text { days }\end{array}$ & $\begin{array}{l}\text { CFQ score improved } \\
\text { from coefficient of } \\
-0.2 \text { at baseline to } \\
-0.17 \text { at } 30 \text { days }\end{array}$ \\
\hline Coleman $1996^{20}$ & $\begin{array}{l}n=70, \text { unipolar } \\
\text { depression }\end{array}$ & SSMQ & $\begin{array}{l}\text { Mixture of bifrontal, } \\
\text { RUL and bilateral }\end{array}$ & $\begin{array}{l}\text { Baseline and } \\
2 \text { months }\end{array}$ & $\begin{array}{l}-31.5 \text { at baseline, } \\
-5.4 \text { at } 2 \text { months }\end{array}$ \\
\hline Ikeji $1999^{13}$ & $\begin{array}{l}n=70 \text { ECT, } n=70 \\
\text { control; } 30 \% \\
\text { unipolar depression; } \\
\text { 37.1\% schizophrenia; } \\
28.6 \% \text { mania; } 4.3 \% \\
\text { schizoaffective } \\
\text { disorders }\end{array}$ & $\begin{array}{l}\text { Two binary questions: } \\
\text { 'Is your memory poor?' } \\
\text { 'Do you worry about } \\
\text { your memory?' }\end{array}$ & Bilateral & $\begin{array}{l}\text { Baseline and } \\
\text { seven intervals } \\
\text { up to } 6 \text { months } \\
\text { post-treatment }\end{array}$ & $\begin{array}{l}\text { Subjective memory } \\
\text { complaints at } 6 \\
\text { months: } 37.1 \% \text { of ECT } \\
\text { group, } 22.6 \% \text { of } \\
\text { control group }\end{array}$ \\
\hline
\end{tabular}

CFQ, Cognitive Failures Questionnaire; ECT, Electroconvulsive Therapy; HRSD, Hamilton Rating Scale for Depression; PRMQ, Prospective and Retrospective Memory Questionnaire; RUL, Right Unilateral; SD, Standard Deviation; SSMQ, Squire Subjective Memory Questionnaire.

improvement immediately post-treatment. Interestingly, at 2 months, their SSMQ scores were no different from the control group who had not received $\mathrm{ECT} .{ }^{20}$ Improvements were closely correlated with mood scores and there was a possible relationship between greater autobiographical memory deficits and subjective memory problem complaints.

\section{Medium-term follow-up: up to 6 months}

A study of 31 patients in Norway measured cognitive function and subjective memory with the Everyday Memory Questionnaire before starting ECT, and at 6 weeks and 6 months post-treatment. ${ }^{23,27}$ There was no statistically 


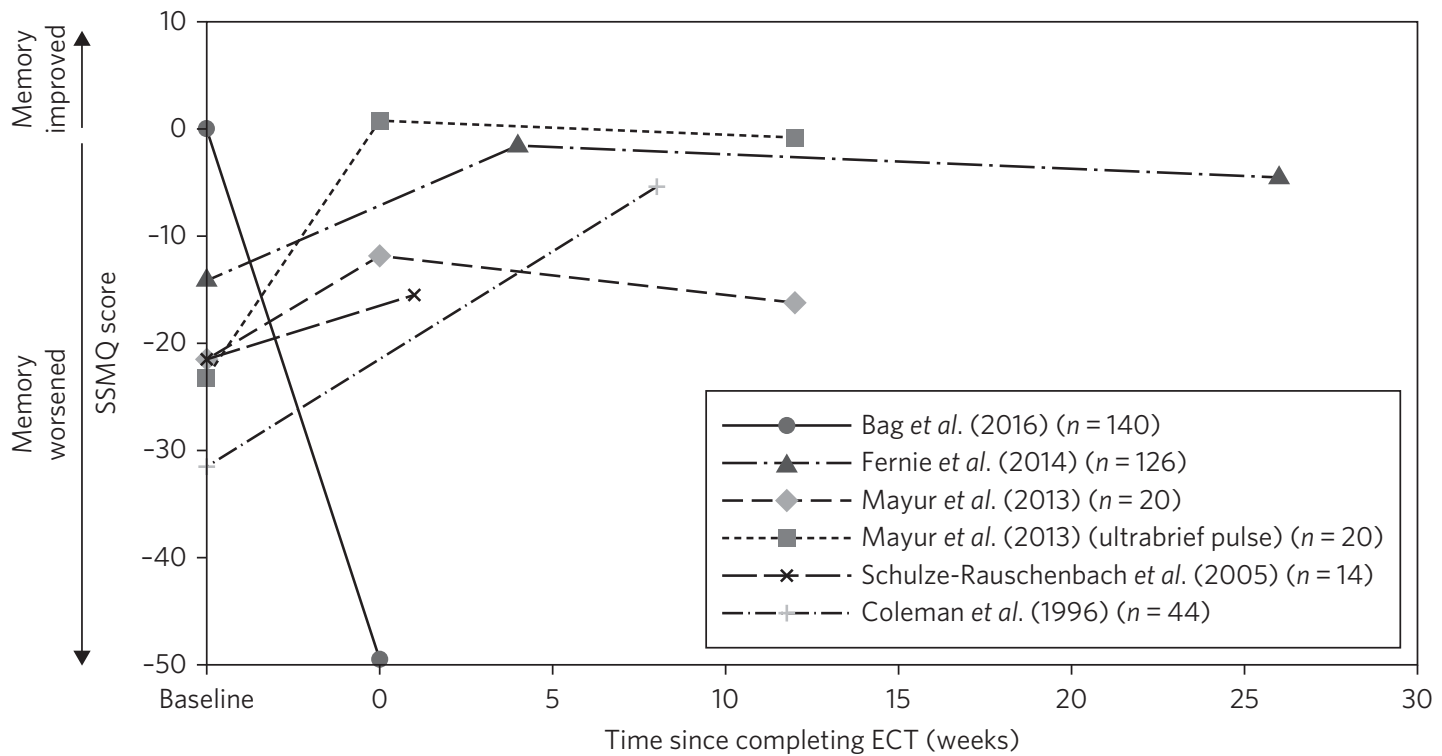

Fig. 2 Subjective memory change over time. A comparison of studies using the Squire Subjective Memory Questionnaire (SSMQ). Studies used brief pulse unless stated otherwise. ${ }^{12,15,16,18,20}$ ECT, Electroconvulsive Therapy.

significant change in subjective memory found between all three time points, suggesting subjective memory complaints were not simply correlated with mood.

A 2014 retrospective case-notes study of 126 patients in the UK found that subjective memory improved at 1 month, 3 month and 6 months after ECT. ${ }^{16}$ This improvement was closely correlated with an improvement in MontgomeryÅsberg Depression Rating Scale score, suggesting a causal link between depression and memory impairment that was reversible by ECT; however, complete information was only available for 56 patients. Further evidence of longerterm positive outcomes were found in a 2010 study of 85 patients that found significant improvements in subjective memory at both 12 and 24 weeks after the end of the acute treatment course. ${ }^{19}$

Comparing sham and real treatment, a study of 70 patients assessed subjective memory with a single yes/no question. The percentage of patients complaining of subjective memory problems had significantly improved at 6 months in three of the four groups (sham versus real; responders versus non-responders) and was no worse in the fourth (real ECT, non-responders). ${ }^{24}$

Using a simple binary question, a Nigerian study $(n=70)$ found that $37.1 \%$ of the ECT group reported subjective memory problems at 6 months compared with $22.6 \%$ of diseasematched controls. ${ }^{13}$ All participants in this study recovered within six treatments, an unusually high response rate that may, when combined with the average age of 29.4 years, limit the generalisability of the findings.

\section{Pulse width}

All four studies that used ultra-brief pulse width reported a low incidence of subjective memory complaints and where a direct comparison was made, ultra-brief pulse width showed fewer side-effects than brief pulse, with no different in treatment effect. ${ }^{2,15,17,21}$
Six weeks after the end of treatment, $73 \%$ of the 48 patients who received ultra-brief therapy in a 2010 study were glad that they had received ECT and satisfaction was correlated with both subjective memory and depression scores. ${ }^{2}$ A 2013 study comparing brief and ultra-brief therapy in 40 patients found improvements in memory at the end of treatment from both brief and ultra-brief pulse widths; however, ultra-brief therapy was superior, resulting in a resolution of memory problems that was sustained at 3-month follow-up, with no difference in treatment efficacy. ${ }^{15}$ A study of 26 patients undergoing ultra-brief ECT who were followed up on daily for 60 days found ultra-brief therapy to have no effect on subjective memory, as assessed by a selection of SSMQ questions. ${ }^{17}$ The majority of patients in this small sample were out-patients, reducing generalisability, and almost $40 \%$ were receiving maintenance ECT.

\section{Limitations}

Heterogeneity of studies

There were considerable differences in patient characteristics across all studies, including average age, diagnosis, gender and modality of ECT, and all combinations of electrode placement positions were used across studies. Within studies, only five delivered ECT with the same electrode placement and pulse width to all patients. This heterogeneity makes it very difficult to determine if any relationship exists between mode of delivery or demographic factors and risk of side-effects. Data on which patients are most vulnerable to ECT side-effects is still lacking. ${ }^{28}$

\section{Ratings scales}

Seven different measures of subjective memory were used across the 16 included studies, making comparison between studies challenging. The SSMQ was the most widely used assessment tool, but doubt remains about how well subjective tools capture actual experience. A study reporting treatment 
satisfaction rates did not find the SSMQ to be an independent predictor variable in their multiple regression model. ${ }^{2}$

A further criticism of rating scales is that they produce a single summary or average score that may mask domainspecific complaints within the questionnaire. Studies using qualitative assessments of memory impairment have found subjective deficits at 24 weeks that were not picked up by scales designed to capture subjective experience. ${ }^{26}$

A key limitation of all studies on ECT is the acceptability of the treatment versus the alternatives, which could include additional or alternative drug therapy or a longer period of illness. Also, with ECT usually being reserved for the most unwell patients, there are issues of impaired insight and recall bias that may undermine the construct validity of any subjective memory questionnaire in this patient population.

\section{Conclusions}

The few studies that assessed subjective memory several months beyond the end of ECT suggest that, on average, subjective memory scores tend to recover over time, with ultra-brief pulse showing fewer side-effects than brief pulse therapy. However, there is considerable heterogeneity both between and within studies, limiting meaningful conclusions. Past and future studies are vulnerable to high drop-out rates, observer bias and concerns over the face validity of standardised instruments designed to measure subjective memory. However, these tools and studies should not be dismissed as being unreflective of patient experience. Contemporaneous quantitative data provides a longitudinal picture, reduces hindsight bias and may be most useful in identifying common risk factors for significant memory loss rather than as a tool for identifying specific deficits. Future subjective memory studies should use the same outcome measure, such as the SSMQ, and measuring subjective memory should become a routine part of ECT treatment and follow-up, ideally allowing an international registry to be created to help us identify those at low and high risk of memory impairment. Comparable outcome measures should ideally be collected for patients receiving alternative treatments.

More qualitative studies are needed to identify common experiences, effects and meaning of any subjective memory loss after treatment, and ultimately, whether this is an acceptable risk from this treatment for major depression. Both of quantitative and qualitative approaches may then be used to develop more sensitive memory assessment tools, providing more informative to both patient and clinician during joint discussions around whether to proceed with a treatment that remains one of the most effective and controversial in medicine.

\section{About the authors}

Dr Simon Vann Jones is an ST5 in old age psychiatry at Cornwall Partnership Foundation Trust, Bodmin, UK. Dr Rick McCollum is a consultant in old age psychiatry at Devon Partnership Trust, Exeter, UK.

\section{References}

1 Tang WK, Ungvari GS, Chan GW. Patients' and their relatives' knowledge of, experience with, attitude toward, and satisfaction with electroconvulsive therapy in Hong Kong, China. J ECT 2002; 18(4): 207-12.

2 Sienaert PA, Vansteelandt K, Demyttenaere K, Peuskens J. Predictors of patient satisfaction after ultrabrief bifrontal and unilateral electroconvulsive therapies for major depression. J ECT 2010; 26(1): 55-9.

3 Apéria B. Hormone pattern and post-treatment attitudes in patients with major depressive disorder given electroconvulsive therapy. Acto Psychiatr Scand 1986; 73(3): 271-4

4 Benbow SM. Patients' views on electroconvulsive therapy on completion of a course of treatment. J ECT 1988; 4(2): 146-52.

5 Bernstein HJ, Beale MD, Burns C, Kellner CH. Patient attitudes about ECT after treatment. Psychiatr Ann 1998; 28(9): 524-7.

6 Sienaert P, De Becker T, Vansteelandt K, Demyttenaere K, Peuskens J. Patient satisfaction after electroconvulsive therapy. J ECT 2005; 21(4): 227-31.

7 Virit O, Ayar D, Savas HA, Yumru M, Selek S. Patients' and their relatives' attitudes toward electroconvulsive therapy in bipolar disorder. $J$ ECT 2007; 23(4): 255-9.

8 Koopowitz LF, Chur-Hansen A, Reid S, Blashki M. The subjective experience of patients who received electroconvulsive therapy. Aust N Z J Psychiatry 2003; 37(1): 49-54.

9 Hoffmann TC, Del Mar C. Clinicians' expectations of the benefits and harms of treatments, screening, and tests: a systematic review. JAMA Intern Med 2017; 177(3): 407-19.

10 Basch E. Patient-reported outcomes-harnessing patients' voices to improve clinical care. N Engl J Med 2017; 376(2): 105-8.

11 Squire LR, Wetzel CD, Slater PC. Memory complaint after electroconvulsive therapy: assessment with a new self-rating instrument. Biological Psychiatry 1979; 14(5): 791-801.

12 Bag S, Canbek O, Atagun IM, Kutlar TM. Early effects of modern electroconvulsive therapy on subjective memory in patients with mania or depression. Indian J Psychiatry 2016; 58(2): 198-203.

13 Ikeji OC, Ohaeri JU, Osahon RO, Agidee RO. Naturalistic comparative study of outcome and cognitive effects of unmodified electroconvulsive therapy in schizophrenia, mania and severe depression in Nigeria. East Afr Med J 1999; 76(11): 644-50

14 Kumar DR, Han HK, Tiller J, Loo CK, Martin DM. A brief measure for assessing patient perceptions of cognitive side effects after electroconvulsive therapy: the subjective assessment of memory impairment. ECT 2016; 32(4): 256-61.

15 Mayur P, Byth K, Harris A. Autobiographical and subjective memory with right unilateral high-dose 0.3 -millisecond ultrabrief-pulse and 1-millisecond brief-pulse electroconvulsive therapy: a double-blind, randomized controlled trial. J ECT 2013; 29(4): 277-82.

16 Fernie G, Bennett DM, Currie J, Perrin JS, Reid IC. Detecting objective and subjective cognitive effects of electroconvulsive therapy: intensity, duration and test utility in a large clinical sample. Psychol Med 2014; 44 (14): 2985-94.

17 Fazzino TL, Rabinowitz T, Althoff RR, Helzer JE. Monitoring daily affective symptoms and memory function using Interactive Voice Response (IVR) in outpatients receiving electroconvulsive therapy. J ECT 2013; 29(4): 318-24.

18 Schulze-Rauschenbach SC, Harms U, Schlaepfer TE, Maier W, Falkai P, Wagner M. Distinctive neurocognitive effects of repetitive transcranial magnetic stimulation and electroconvulsive therapy in major depression. Br J Psychiatry 2005; 186(5): 410-6.

19 Smith GE, Rasmussen KG Jr, Cullum CM, Felmlee-Devine MD, Petrides $G$, Rummans $T A$, et al. A randomized controlled trial comparing the memory effects of continuation electroconvulsive therapy $v$. continuation pharmacotherapy: results from the Consortium for Research in ECT (CORE) study. J Clin Psychiatry 2010; 71(2): 185-93.

20 Coleman EA, Sackeim HA, Prudic J, Devanand DP, McElhiney MC, Moody BJ. Subjective memory complaints prior to and following electroconvulsive therapy. Biol Psychiatry 1996; 39(5): 346-56.

21 Brus $O$, Nordanskog $P$, Båve U, Cao $Y$, Hammar $\AA$, Landén $M$, et al Subjective memory immediately following electroconvulsive therapy. ECT 2017; 33(2): 96-103. 
$22 \mathrm{Ng} \mathrm{C}$, Schweitzer I, Alexopoulos P, Celi E, Wong L, Tuckwell V, et al. Efficacy and cognitive effects of right unilateral electroconvulsive therapy. J ECT 2000; 16(4): 370-9.

23 Mohn C, Rund BR. Maintained improvement of neurocognitive function in major depressive disorders 6 months after ECT. Front Psychiatry 2016; 7: 200.

24 Frith $C D$, Stevens $M$, Johnstone EC, Deakin JF, Lawler P, Crow TJ Effects of ECT and depression on various aspects of memory. $\mathrm{Br} J$ Psychiatry 1983; 142(6): 610-7.

25 Arts $B$, Peters $M$, Ponds R, Honig A, Menheere P, van Os J. S100 and impact of ECT on depression and cognition. J ECT 2006; 22(3): 206-12.
26 Berman RM, Prudic J, Brakemeier EL, Olfson M, Sackeim HA. Subjective evaluation of the therapeutic and cognitive effects of electroconvulsive therapy. Brain Stimulat 2008; 1(1): 16-26.

27 Mohn C, Rund BR. Significantly improved neurocognitive function in major depressive disorders 6 weeks after ECT. J Affect Disord 2016; 202: $10-5$.

28 Prudic J, Peyser S, Sackeim HA. Subjective memory complaints: a review of patient self-assessment of memory after electroconvulsive therapy. J ECT 2000; 16(2): 121-32.

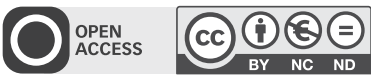

